\title{
Sediment flow paths and associated organic carbon dynamics across a Mediterranean catchment
}

\author{
C. Boix-Fayos ${ }^{1}$, E. Nadeu ${ }^{1}$, J. M. Quiñonero ${ }^{2}$, M. Martínez-Mena ${ }^{1}$, M. Almagro ${ }^{1}$, and J. de Vente ${ }^{1}$ \\ ${ }^{1}$ Soil Erosion and Conservation Research Group, CEBAS-CSIC, Spanish Research Council, Campus de Espinardo 30100, \\ P.O. Box 164, Murcia, Spain \\ ${ }^{2}$ Department of Geography, University of Murcia, Campus de la Merced, 30001 Murcia, Spain \\ Correspondence to: C. Boix-Fayos (cboix@cebas.csic.es)
}

Received: 28 February 2014 - Published in Hydrol. Earth Syst. Sci. Discuss.: 15 May 2014

Revised: 21 November 2014 - Accepted: 4 February 2015 - Published: 3 March 2015

\begin{abstract}
Terrestrial sedimentation buries large amounts of organic carbon (OC) annually, contributing to the terrestrial carbon sink. The temporal significance of this sink will strongly depend on the attributes of the depositional environment, but also on the characteristics of the OC reaching these sites and its stability upon deposition. The goal of this study was to characterise the OC during transport and stored in the depositional settings of a mediumsized catchment $\left(111 \mathrm{~km}^{2}\right)$ in SE Spain, to better understand how soil erosion and sediment transport processes determine catchment-scale OC redistribution. Total organic carbon (TOC), mineral-associated organic carbon (MOC), particulate organic carbon (POC), total nitrogen $(\mathrm{N})$ and particle size distributions were determined for soils (i), suspended sediments (ii) and sediments stored in a variety of sinks such as sediment wedges behind check dams (iii), channel bars (iv), a small delta in the conjunction of the channel and a reservoir downstream (v), and the reservoir at the outlet of the catchment (vi). The data show that the OC content of sediments was approximately half of that in soils $\left(9.42 \pm 9.01 \mathrm{~g} \mathrm{~kg}^{-1}\right.$ versus $20.45 \pm 7.71 \mathrm{~g} \mathrm{~kg}^{-1}$, respectively) with important variation between sediment deposits. Selectivity of mineral and organic material during transport and deposition increased in a downstream direction. The mineralisation, burial or in situ incorporation of OC in deposited sediments depended on their transport processes and on their post-sedimentary conditions. Upstream sediments (alluvial wedges) showed low OC contents because they were partially mobilised by non-selective erosion processes affecting deeper soil layers and with low selectivity of grain sizes (e.g. gully and bank erosion). We hypothesise that
\end{abstract}

the relatively short transport distances, the effective preservation of OC in microaggregates and the burial of sediments in the alluvial wedges gave rise to low OC mineralisation, as is arguably indicated by $\mathrm{C}: \mathrm{N}$ ratios similar to those in soils. Deposits in middle stream areas (fluvial bars) were enriched in sand, selected upon deposition and had low OC concentrations. Downstream, sediment transported over longer distances was more selected, poorly microaggregated, and with a prevalence of silt and clay fractions and MOC pool. Overall, the study shows that OC redistribution in the studied catchment is highly complex, and that the results obtained at finer scales cannot be extrapolated at catchment scale. Selectivity of particles during detachment and transport, and protection of OC during transport and deposition are key for the concentration and quality of $\mathrm{OC}$ found at different depositional settings. Hence, eco-geomorphological processes during the different phases of the erosion cycle have important consequences for the temporal stability and preservation of the buried OC and in turn for the OC budget.

\section{Introduction}

Terrestrial ecosystems have captured up to $28 \%$ $\left(2.6 \pm 0.8 \mathrm{Pg} \mathrm{yr}^{-1}\right)$ of the $\mathrm{CO}_{2}$ emitted annually over the last decade (Le Quéré et al., 2013). Among the processes involved in this terrestrial carbon (C) sink, terrestrial sedimentation of eroded soil and replacement of soil organic carbon at eroding sites have been regarded as active components (Stallard, 1998; Harden et al., 1999; Van Oost et al., 2007). The magnitude of its contribution to the sink has 
been estimated by some to be between 0.6 and $1.5 \mathrm{Pg}$ of $\mathrm{C}$ annually (Stallard, 1998; Aufdenkampe et al., 2011) through the burial of large quantities of laterally transported organic carbon (OC). The significance of this contribution, however, will depend on the long-term preservation of the buried OC, an issue that remains under debate (Van Oost et al., 2012 and references therein). The fate of the redistributed OC will ultimately depend on the mechanisms of its physical and chemical protection against decomposition, its turnover rates and the conditions under which the $\mathrm{OC}$ is stored in sedimentary settings (Van Hemelryck et al., 2011; Berhe and Kleber, 2013).

The study of the temporal evolution of buried OC at depositional sites can be approached from different and complementary perspectives. It has been observed that organic matter exported from rivers into the sea is not necessarily identical to the organic matter of the plants and soils upstream in the river catchments (Raymond and Bauer, 2001). This indicates that tracing sediment from source areas and the processes taking place during transport and deposition of eroded OC can also provide information on the quality and dynamics of the eroded OC (Nadeu et al., 2012 and references therein). Actually, more than $90 \%$ of the sediment generated annually in uplands is not exported from catchments (Trimble, 1983; Meade and Stevens Jr., 1990; Walling and Fang, 2003) but remains in transitory depositional sites such as lakes and reservoirs, colluvial deposits at the bases of hillslopes, alluvium in floodplains and channel bars (Meade and Stevens Jr., 1990). In fact, flood plains are expected to represent a key storage site for $\mathrm{OC}$ within the catchment $\mathrm{C}$ balance and, increasingly, this function is fulfilled by reservoirs (Verstraeten et al., 2006; Wisser et al., 2013; Ran et al., 2014). Although large efforts are being made to understand the flow paths of $\mathrm{OC}$ at the catchment scale, most of the abovementioned $\mathrm{C}$ sinks remain unquantified. Recently, Ran et al. (2014) have estimated an OC budget for the Yellow River, concluding that over a period of 60 years, $49.5 \%$ of the OC was buried in different sinks within the river system, $27 \%$ was mineralised during the erosion and transport phases and $23.5 \%$ was delivered into the ocean. However, there is still large uncertainty over the stability and residence times of OC in many of these sinks, which are affected greatly by geomorphological and hydrological dynamics (Hoffmann et al., 2013). Thus, characterising the OC at these transitory settings and acquiring knowledge on the processes and factors that influence OC stability at these sites contribute to the assessment of the significance of terrestrial deposition in the $\mathrm{C}$ cycle.

Understanding how OC moves along with sediments through the different phases and types of erosion and transport processes is crucial to explain, partially, the large variation in $\mathrm{C}$ contents found in depositional sites. Along these lines, progressively the geomorphic factors that control the redistribution of OC within watersheds are being defined (Berhe and Kleber, 2013; Evans et al., 2013; Hoffmann et al.,
2013; Nadeu et al., 2011, 2015). The study of OC transport from erosion sites to depositional settings implies the consideration of a large number of factors and processes taking place. Several studies have described the impact of variation of transport and deposition of different OC size fractions and the role of OC mineralisation, as well as the breakdown of soil aggregates or re-aggregation at depositional sites (Wang et al., 2010; Van Hemelryck et al., 2011; Martínez-Mena et al., 2012), and the contribution of new OC formation from vegetation at depositional settings. Altogether, these factors are considered responsible for the transformations undergone by OC from source to sink. Yet, comprehensive studies of source to sink processes are, to the best of our knowledge, lacking.

The objective of this study is to characterise the OC in transit and at a range of depositional settings (Table 1) in a medium size catchment (Fig. 1) and to associate our observations with the catchment sediment dynamics. We aimed to (i) characterise the OC concentrations in the main sedimentary deposits along the catchment's drainage system, (ii) assess the main processes involved in sediment redistribution, and (iii) establish links between these processes and the OC concentration and quality.

\section{Study area}

The study area is located in the headwaters of the Segura catchment (Murcia, SE Spain), which drains to the Taibilla reservoir (Turrilla catchment) and is formed by three adjacent subcatchments (Rogativa, Arroyo Blanco and Arroyo Tercero) covering a total area of $\sim 111 \mathrm{~km}^{2}$ (Fig. 1). The Taibilla reservoir, built in 1974, provides water to more than 2 million people. The dominant lithology of the catchment consists of marls, limestones, marly limestones and sandstones of the Cretaceous, Oligocene and Miocene. The mountains are mainly constituted by limestones, while the middle and bottom valley sections are dominated by marls (IGME, 1978).

The average annual rainfall for the period 1933-2004 was $583 \mathrm{~mm}$ and the average annual temperature $13.3^{\circ} \mathrm{C}$ at a station located in the centre of the basin at $1200 \mathrm{~m}$ a.s.l. (above sea level). Snow in the mountains, especially above 1700 $\mathrm{m}$, is not abundant but is frequent in winter. The dominant soils in the area are Lithosols, Regosols and Cambisols (IUSS Working Group WRB, 2006). They have an average OC concentration in the first $10 \mathrm{~cm}$ of between 3.2 and $1 \%$ depending on the land use, being the lowest for agricultural use mainly on marl lithology (Nadeu et al., 2014). A previous study at the site showed that OC concentration in soil profiles down to $1 \mathrm{~m}$ was $1.5 \pm 1.4 \%$ and $2.2 \pm 1 \%$ in profiles located in forest areas in two Rogativa subcatchments. In both subcatchments average OC concentrations in channel sediments down to $80 \mathrm{~cm}$ were $1.1 \pm 0 \%$ and $1.4 \pm 0.1 \%$, respectively (Nadeu et al., 2012). Boix-Fayos et al. (2009) attributed variation of OC concentration in depth in sedi- 


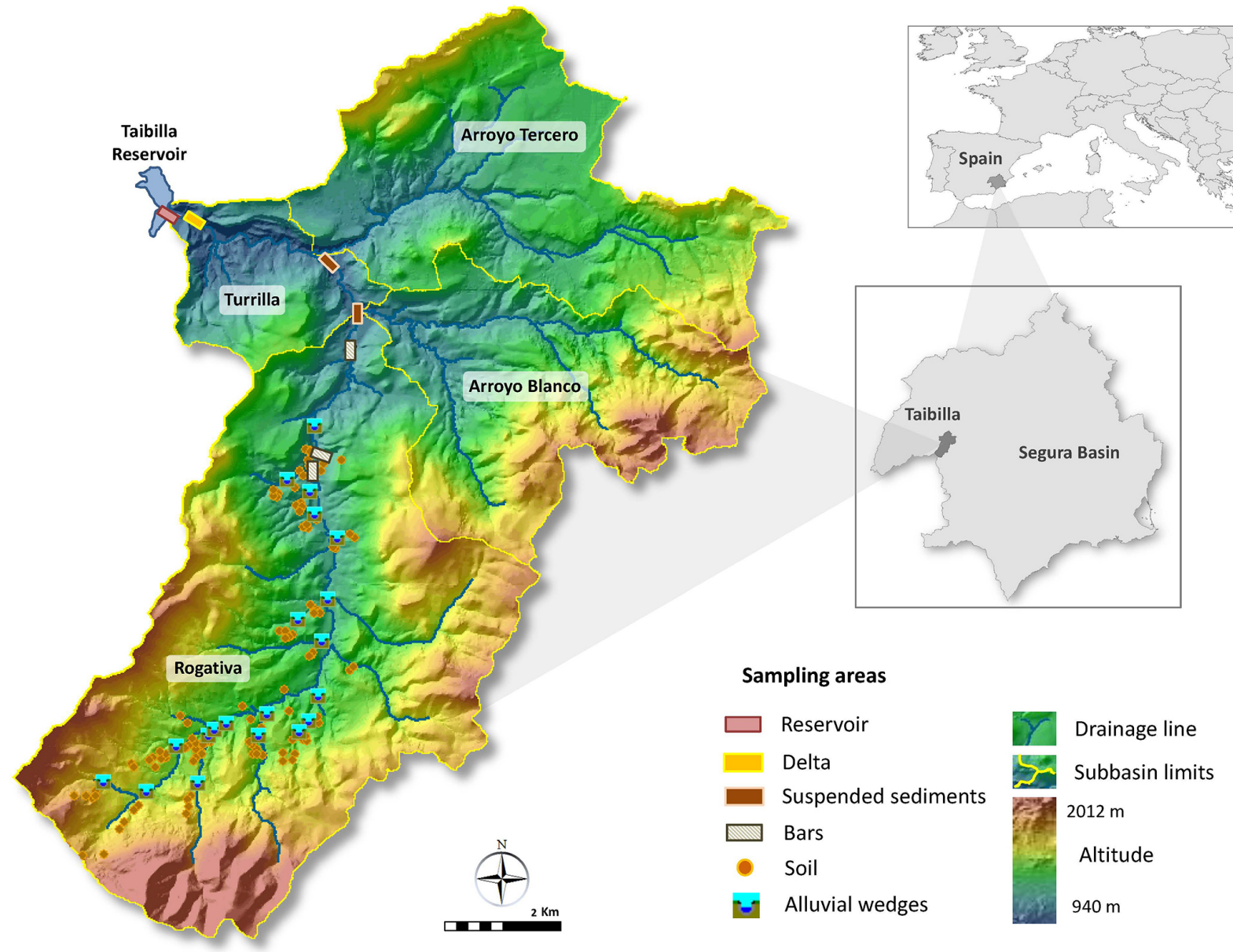

Figure 1. Location of the study area and sampling scheme.

ment profiles down to $120 \mathrm{~cm}$, located in the main channel of seven subcatchments of Rogativa, to changes in the land use pattern of the drainage area over the last decades.

The landscape is a mix of dryland farming (mainly barley), plantations of walnuts (Juglans regia L.), forests and shrublands. The forest is dominated by Pinus nigra Arn. subsp. salzmannii, although some individuals and masses of Pinus pinaster Ait. and Pinus halepensis Mill. are located in the lowest parts of the basin. A relevant proportion of the pine forest was planted in the reforestation works associated with dam construction in the 1970s. Nowadays, masses of Quercus rotundifolia Lam. are isolated or associated with $P$. nigra subsp. salzmannii.

The catchment has been affected by important land use changes since the second half of the twentieth century. These changes consisted mainly of a progressive abandonment of the dryland farming activities and an increase of the forest cover. In the 1970s, a network of check dams was installed. Previous studies highlighted the important impact of land use changes and check dams on the catchment's sedimentary dynamics (Boix-Fayos et al., 2008; Quiñonero-Rubio et al., 2013, 2014), causing important morphological changes in the river bed and accelerating bank erosion processes (BoixFayos et al., 2007). Land use changes have been estimated to be responsible for about $50 \%$ of the reduction in catchment sediment yield (Boix-Fayos et al., 2008) and have had an important impact on the soil carbon stocks of the catchment (Boix-Fayos et al., 2009).

The Turrilla catchment shows a dendritic channel pattern. The main channel has an average slope of $7.7^{\circ}$ and a total longitude of $22 \mathrm{~km}$. The stream is discontinuous upstream and continuous downstream. Geomorphological characterisations of channel reaches along the main and tributary streams of the Rogativa catchment indicated dominance of non-selective erosion processes affecting deeper soil layers and with no selectivity of grain sizes, such as gully, bank and river bed erosion (Nadeu et al., 2012), often activated as a consequence of the decrease in sediment input from the adjacent slopes caused by a generalised recovery of the vegetation, following agricultural land abandonment and reforestations (Nadeu et al., 2014). Furthermore, land use and morphological characteristics of the drainage area were identified to be important driving factors determining the concentration and organic carbon yield exported by lateral fluxes 
Table 1. Main location and characteristics of the sampling areas within the catchment.

\begin{tabular}{|c|c|c|c|c|c|c|}
\hline $\begin{array}{l}\text { Location of soil } \\
\text { and sediments }\end{array}$ & $\begin{array}{l}\text { Group } \\
\text { name }\end{array}$ & $\begin{array}{l}\text { Drainage } \\
\text { area (ha) }\end{array}$ & Deposition areas & $\begin{array}{c}\text { Profiles/ } \\
\text { subcatchments/ } \\
\text { events }\end{array}$ & $\begin{array}{l}\text { Maximum } \\
\text { depth } \\
(\mathrm{cm})\end{array}$ & $\begin{array}{l}\text { Samples } \\
\quad(n)\end{array}$ \\
\hline \multicolumn{7}{|c|}{ Soils } \\
\hline Slopes & Soils & 11000 & & 109 & 10 & 109 \\
\hline \multicolumn{7}{|c|}{ Sediments } \\
\hline $\begin{array}{l}\text { Subcatchments } \\
\text { in the third- and } \\
\text { fourth-order } \\
\text { channels }\end{array}$ & Wedges & $8-146$ & $\begin{array}{c}\text { Sediment wedges } \\
\text { behind check } \\
\text { dams }\end{array}$ & 19 & 125 & 537 \\
\hline $\begin{array}{c}\text { Main channel } \\
\text { and a tributary } \\
\text { stream }\end{array}$ & Bars & 5000 & Channel bars & 10 & $3-30$ & 46 \\
\hline Main channel & $\begin{array}{l}\text { Suspended } \\
\text { sediment }\end{array}$ & $5000-7800$ & Suspended load & 13 & $7-42$ & 69 \\
\hline Main channel & Delta & 11000 & $\begin{array}{l}\text { Delta in the } \\
\text { conjunction of } \\
\text { the main channel } \\
\text { and reservoir }\end{array}$ & 6 & 10 & 24 \\
\hline Reservoir & Reservoir & 32000 & $\begin{array}{c}\text { Reservoir } \\
\text { sediments at the } \\
\text { exit of the } \\
\text { catchment }\end{array}$ & 2 & 100 & 23 \\
\hline
\end{tabular}

in smaller subcatchments of the Rogativa watershed (Nadeu et al., 2015). In general terms, the main channel of Rogativa moved from an aggradation period with large sediment volumes coming from a well-connected agricultural catchment (1950s-1980s), to an incision and degradation phase after afforestation, land abandonment and hydrological control works (Boix-Fayos et al., 2007). Nowadays, the Rogativa catchment is under a transition phase with an armoured main channel and sediments are being incorporated in the channel through gullies and bank erosion (Boix-Fayos et al., 2007; Nadeu et al., 2011).

\section{Methods}

The field experimental design was based on the main pathways of sediment and soil OC during their transport through the catchment. Therefore, soils and different sedimentary deposits within the catchment were sampled as shown in Table 1 and Fig. 2.

\subsection{Soil data}

Topsoil $(0-10 \mathrm{~cm})$ samples were taken from 109 locations distributed from upstream to downstream in the catchment, representing all land uses and their spatial extent. Of these samples, $20 \%$ were from high-density forest soils, $30 \%$ from low-density forest soils, $20 \%$ from shrubland soils, $10 \%$ from pasture soils and $20 \%$ from agricultural soils. Disturbed samples were taken for laboratory analyses and undisturbed samples (rings of $100 \mathrm{~cm}^{3}$ ) for estimating soil bulk density.

\subsection{Sediment data}

\subsubsection{Alluvial wedges (behind check dams)}

The sediment deposited behind the network of check dams installed in the 1970s was used as representative of material mobilised by erosion processes and fluvial transport from the upper catchment areas (Figs. 1, 2). A total of 19 (sub) catchments, evenly distributed, were sampled. The sediment wedges deposited behind each check dam were sampled at the front (close to the check dam) to a maximum depth of $1.25 \mathrm{~m}$. In addition, 14 of the sediment wedges were sampled also at the back of the sediment wedge, to a maximum depth of $96 \mathrm{~cm}$. At all points, bulk samples of $100 \mathrm{~cm}^{3}$ were taken at intervals of $7 \mathrm{~cm}$ depth until the maximum depth was reached. Moreover, for 14 wedges, replicate samples of the first layers were taken at $7 \mathrm{~cm}$ intervals, to $35 \mathrm{~cm}$ depth. A total of 537 undisturbed samples were collected. 


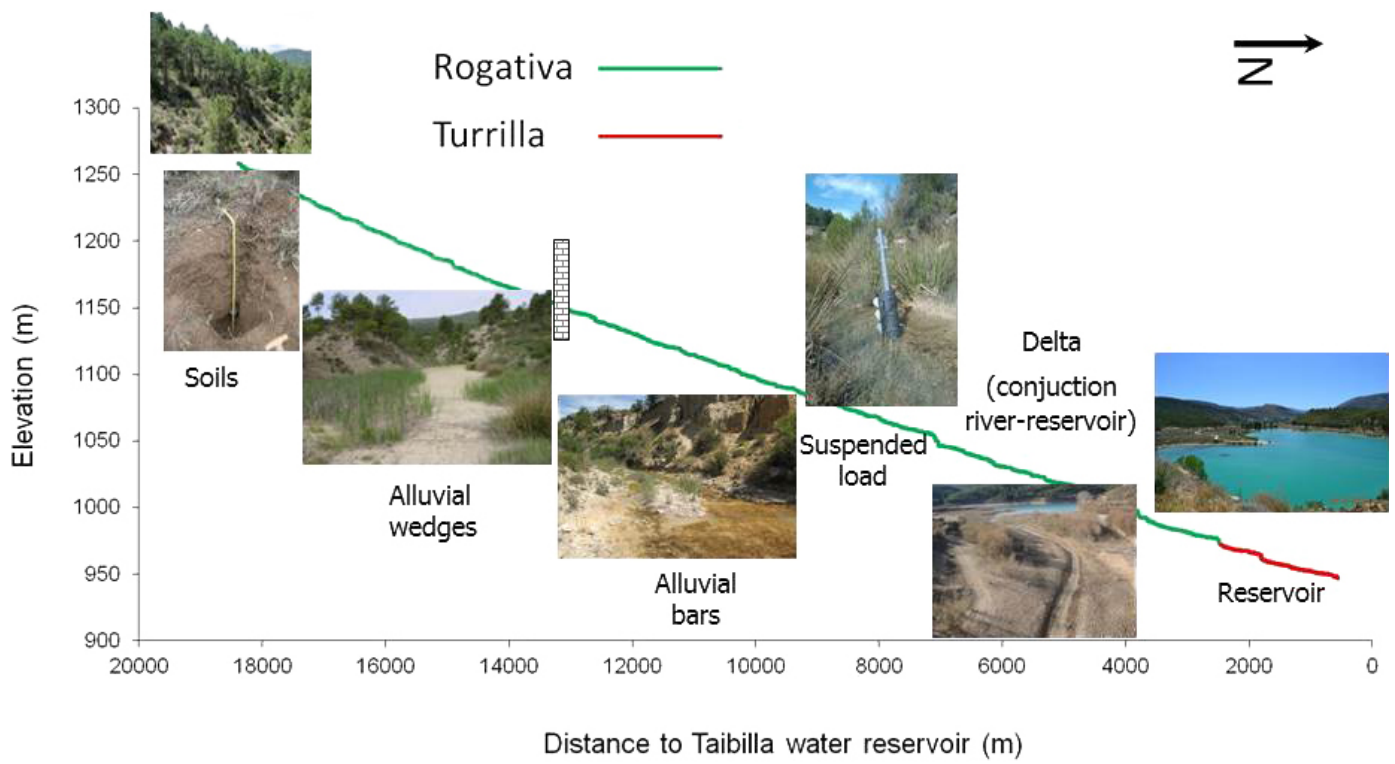

Figure 2. Sketch representing the morphological positions selected for sampling of soil and sediments. Soils were sampled all around the catchment in all the different land use classes, alluvial wedges behind check dams predominantly in the upper and middle parts of the catchment, while alluvial bars and suspended solids were sampled in the middle and downstream areas. Delta and reservoir represent sampling areas downstream.

\subsubsection{Fluvial bars}

Sedimentary fluvial bars located at two different reaches in the Rogativa main stream, $2 \mathrm{~km}$ apart in the middle section of the catchment, were sampled. One of the reaches is a permanent-flow reach where four different bars were sampled during three seasons (autumn 2009, winter and spring 2010), and the other is an intermittent reach where four bars were sampled in autumn 2009 and winter 2010 (the same dates as the bars of the permanent-flow reach). A disturbed sample of the first $5 \mathrm{~cm}$ of the bar was taken at each sampling period, as no different layers corresponding to different events could be distinguished in these bars.

Two more bars, also in an intermittent reach in the middle section of the catchment and in a confluence of a small subcatchment (11 ha, Barranco Escalerica 2) and the Rogativa main stream, were sampled. The bars in the stream bed were incised during the last runoff event (winter 2010) that took place a few days before the sampling. The deposited layers corresponding to different runoff events could be identified (Figs. 1,2) and were sampled to a maximum depth of $30 \mathrm{~cm}$ (bar 1, seven layers, average depth of each layer $4.2 \mathrm{~cm}$ ) or $20 \mathrm{~cm}$ (bar 2, six layers, average depth of each layer $3.3 \mathrm{~cm}$ ). These bars represented a mixture of sediments coming from several erosion processes and were considered representative of the type of sediment being transported along the stream bed from further upstream (Nadeu et al., 2011). A total of 46 samples were collected.

\subsubsection{Suspended sediment}

Two devices for the sampling of suspended sediments were installed in the main stream of the Rogativa channel in October 2010: one was installed in the downstream area, draining a catchment area of $54.4 \mathrm{~km}^{2}$, and the other was installed below the confluence with the perennial stream of Arroyo Blanco, draining a total catchment area of $78.1 \mathrm{~km}^{2}$.

The sampling devices consisted of a column of six bottles located at an averaged height difference of $7.5 \mathrm{~cm}$ from each other (Figs. 1, 2). At both locations the upper bottle represented bank-full conditions of the incised stream. A total of 69 samples, corresponding to 13 events over a 2.5 year period were collected.

\subsubsection{Delta sediments}

Sediments in the confluence of the river channel and the reservoir were sampled. This delta area is characterised by a very gentle slope and point bars formed by the meandering contact between the river and the reservoir. A sampling scheme following the convex depositional areas of the meanders of the river towards the reservoir was implemented: a total of six positions with two replicates and two depths $(0-5$, $5-10 \mathrm{~cm}$ ) were sampled, collecting a total of 24 samples.

\subsubsection{Reservoir sediments}

Sediments in the Taibilla reservoir were sampled in March 2010. Water height in the Taibilla reservoir is highly variable between years and during the year. Samples were 
taken at a distance of $500 \mathrm{~m}$ from the confluence of the main stream of Rogativa and the reservoir, in exposed sediments forming a terrace $20 \mathrm{~cm}$ above the water level at the moment of sampling. Sampling was done with a Cobra TT hydraulic hammer to a depth of $1 \mathrm{~m}$. The $1 \mathrm{~m}$ deep core was divided at $5 \mathrm{~cm}$ intervals to $20 \mathrm{~cm}$ depth and then at $10 \mathrm{~cm}$ intervals. A total of 23 samples were analysed.

\subsection{Laboratory analysis}

All soil and sediment samples (from erosion deposits and deposition bars) were air-dried or dried in an oven at a low temperature $\left(<60^{\circ}\right)$ and then sieved at $2 \mathrm{~mm}$. Primary particle size distribution was measured using a combination of wet sieving (particles $>63 \mu \mathrm{m}$ ) and laser diffractometry (particles $<63 \mu \mathrm{m}$ ) using a Coulter LS, for the sand fraction and the silt and clay fractions, respectively. The organic matter in these samples was oxidised with hydrogen peroxide and chemically dispersed with a mixture of sodium hexametaphosphate and sodium carbonate (anhydrous) for $18-24 \mathrm{~h}$. The fractions obtained were classified as coarse sand $(2000-250 \mu \mathrm{m})$, fine sand $(250-63 \mu \mathrm{m})$, coarse silt (63$20 \mu \mathrm{m})$, fine silt $(20-2 \mu \mathrm{m})$ and clay $(<2 \mu \mathrm{m})$. The effective particle size distribution was measured by introducing airdried samples into a Coulter LS, without previous physical or chemical dispersion. From these two measurements, microaggregation indices were derived.

The percentage of microaggregated particles of fine sand, coarse silt and fine silt sizes and two aggregation indices that give an indication of the total percentage of microaggregated particles were used: IA (index of aggregation), as the sum of the differences of the dispersed and non-dispersed material in each size group (Wang et al., 2010), and ASC (aggregation silt and clay) as the difference between dispersed clay and silt and non-dispersed clay and silt (Igwe, 2000).

Given that soil carbon pools might have differences in turnover times, it is of high interest to evaluate the behaviour of different carbon pools separately, as this could give us insight into the long-term stability of the mobilised carbon by lateral fluxes. For this purpose the $\mathrm{OC}$ was divided into physical fractions by wet sieving: particulate organic carbon $(>53 \mu \mathrm{m})$ (POC) was separated from mineral associated organic carbon $(<53 \mu \mathrm{m})$ (MOC) after shaking $10 \mathrm{~g}$ of air-dried soil sieved at $2 \mathrm{~mm}$ with $50 \mathrm{~mL}$ of sodium hexametaphosphate for $18 \mathrm{~h}$ (Cambardella and Elliot, 1992). Fractions were oven-dried at $60^{\circ} \mathrm{C}$ for water evaporation and the dry material was weighed prior to $\mathrm{OC}$ determination. The OC and nitrogen contents were determined by dry combustion in an elemental analyser (FLASH EA 1112 Series Thermo). The total organic carbon (TOC) was assumed to be the sum of the POC and MOC. The MOC accounted for microaggregate and intra-aggregate $\mathrm{OC}$ in the silt and clay size fractions. Duplicate or triplicate soil samples were used for laboratory analysis.

\subsection{Statistical analysis}

Significant differences between averages were tested using the non-parametric Kruskal-Wallis $(\mathrm{K}-\mathrm{W})$ test at $p<0.05$. Spearman correlations were performed to explore the relationships between the TOC and pools, as well as $\mathrm{C}: \mathrm{N}$ ratios and the percentages of primary and microaggregated soil particles, together with different aggregation indexes, for all cases or each sediment reservoir type separately. All statistical analyses were performed with the software SPSS 19.0 (SPSS, Chicago, IL).

\section{Results}

\subsection{Primary particle size distribution of soils and sediments}

The particle size distribution of soils differed from that of most of the sediments (Fig. 3). The alluvial bars showed, on average, higher sand contents and lower contents in the fine fractions than the soils (Fig. 3). This enrichment in coarse fractions in the alluvial bars was accompanied by the lowest TOC (Fig. 4a). In contrast, the suspended solids and the delta and reservoir sediments had higher percentages of silt and clay than the soils. The high sand contents in the reservoir and delta sediments were similar to the sand content (around $20 \%$ ) of the wedges. The particle size distributions of the alluvial wedges were more similar to those of the soils of the catchment than to those of the rest of the deposits (Fig. 3).

\subsection{Microaggregated particles in soils and sediments}

Based on the microaggregation data, two groups can be distinguished. Soils and sediment wedges with similar IA and ASC values (Table 2) showed a significantly higher microaggregation level than suspended sediment and reservoir sediments. The sediments in alluvial wedges had 10 times more large aggregates $(250-63 \mu \mathrm{m})$ than the suspended sediment and 6 times more than the reservoir sediments. This was the dominant class in soils and alluvial wedges, while no differences between size classes occurred in suspended and reservoir sediments. The percentages of medium-sized microaggregates $(63-20 \mu \mathrm{m})$ in the alluvial wedges were around 3 and 7 times greater than in the suspended sediment and reservoir sediments, respectively. No significant differences were found between the percentages of microaggregated particles in the suspended sediment and reservoir sediments, regarding the total microaggregated material and size classes.

\subsection{Organic carbon and nitrogen in soils and sediments}

The TOC concentrations of sediments were, on average, around half $\left(9.42 \pm 9.01 \mathrm{~g} \mathrm{~kg}^{-1}\right)$ of the average TOC concentrations of surface soils $(0-10 \mathrm{~cm})\left(20.45 \pm 7.71 \mathrm{~g} \mathrm{~kg}^{-1}\right)$, being higher in alluvial wedges behind dams, in the sus- 

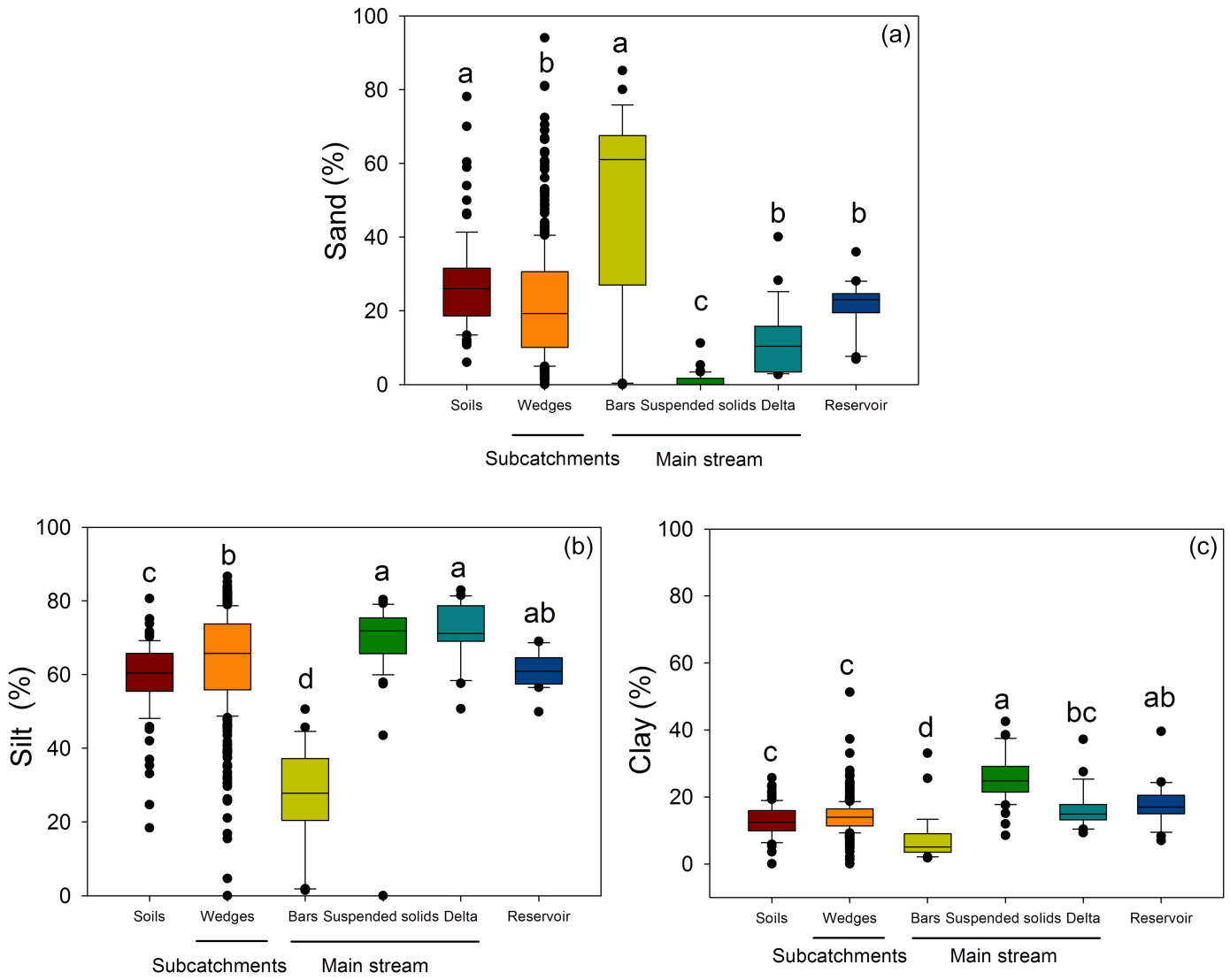

Figure 3. Median, percentiles (10th, 25th, 75th and 90th) and error of the main textural classes (A, sand; B, silt; C, clay) of the different types of sedimentary deposits within the Turrilla catchment. Different letters mean significant differences according to the Kruskal-Wallis test $(p<0.05)$.

pended solids, in the delta and in the reservoir and lower in alluvial bars in the main channel $\left(4.44 \pm 1.98 \mathrm{~g} \mathrm{~kg}^{-1}\right)$ (Fig. 4).

The highest POC content was observed in sediment samples taken from the alluvial wedges, while suspended solids and reservoir profiles contained the highest contents of MOC. The lowest MOC content was found in the bars (Fig. 4a and b). Similar POC: MOC ratios were found on soils, wedges and bars (ranging from 0.5 in bars to 0.8 in soils), whereas much lower POC: MOC ratios were found for the delta and reservoir $(\sim 0.2)$, reflecting the prevalence of the MOC pool transported downstream (Figs. 4c, 5b). Furthermore, while $\mathrm{C}: \mathrm{N}$ ratios of the $\mathrm{MOC}$ and $\mathrm{POC}$ fractions of soils sampled under different land uses in the catchment did not show significant differences (data not shown, $\mathrm{K}-\mathrm{W}$ test, $p>0.05$ ), most of the sediment deposits (except for alluvial wedges) showed significantly lower $\mathrm{C}: \mathrm{N}$ ratios than soils (Fig. 5a). In general, a decrease of $\mathrm{C}: \mathrm{N}$ ratios of sediment deposits along the fluvial path was accompanied by a simultaneous decrease in $\mathrm{N}$, with the exception of suspended load, in which a higher $\mathrm{N}$ content was found than in the other deposits (data not shown, $\mathrm{K}-\mathrm{W}$ test, $p<0.05$ ).

\subsection{Correlations between primary and microaggregated particles, $\mathrm{OC}$ pools and $\mathrm{C}: \mathrm{N}$ ratios}

The Spearman correlation coefficients showed different patterns in the relationships between the percentages of primary and microaggregated particles and the $\mathrm{OC}$ pools and $\mathrm{C}: \mathrm{N}$ ratios across the deposit types (Table 3 ). The index of aggregation (IA total amount of microaggregated particles) was positively correlated with TOC (for all data) and for the suspended sediment $(p<0.06)$, POC (for all data and alluvial wedges) and $\mathrm{C}: \mathrm{N}$ ratio (of all data). Furthermore, the percentages of microaggregates of $250-63 \mu \mathrm{m}$ were positively correlated with POC for all data and alluvial wedges and negatively with the $\mathrm{C}: \mathrm{N}$ ratio (for wedges and suspended sediments). Percentages of microaggregates of 63 $20 \mu \mathrm{m}$ were positively correlated to TOC and MOC of all deposits data and of alluvial wedges. Furthermore this microaggregate size was positively correlated to $\mathrm{C}: \mathrm{N}$ of all data, soils and wedges. The smallest microaggregated particles $(20-2 \mu \mathrm{m})$ were positively correlated to TOC and MOC of the reservoir and to POC of all data. In contrast, the ASC index (microaggregated material of silt and clay size frac- 

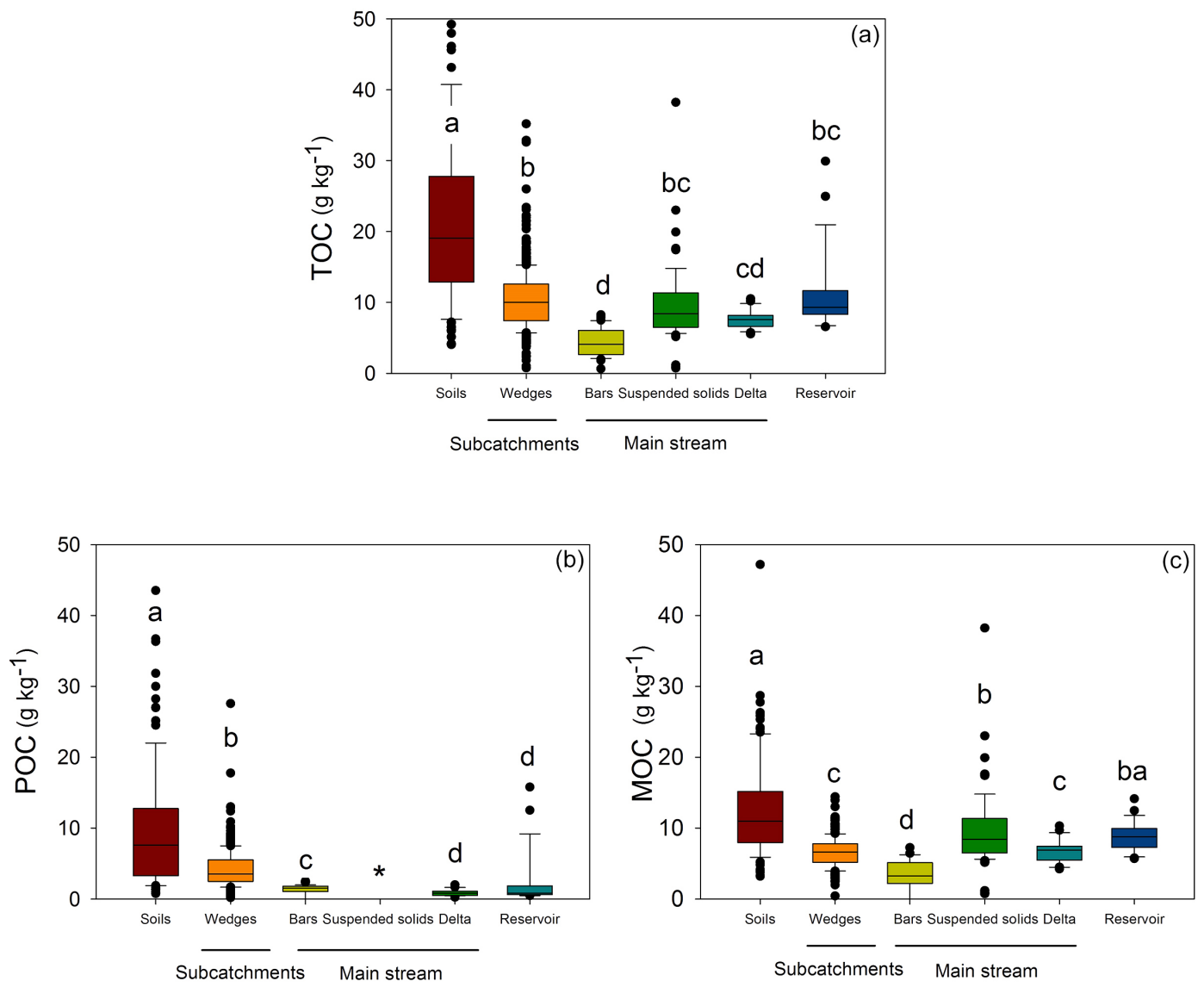

Figure 4. Median, percentiles (10th, 25th, 75th and 90th) and error of the total organic carbon concentration (TOC) (A), particulate organic carbon (POC) (B), and mineral associated organic carbon (MOC) (C) of soils and sediments within the Turrilla catchment. Different letters (a-e) indicate significant differences according to the Kruskal-Wallis test $(p<0.05) .{ }^{*}-$ the suspended solids measured contained only the MOC fraction.

tions) was negatively correlated with the OC pools, only in the cases where no correlation with fine-sized microaggregates $(20-2 \mu \mathrm{m})$ was found. ASC correlated also negatively with $\mathrm{C}: \mathrm{N}$ ratios for all data, soils and alluvial wedges. In general, it seemed that the TOC content and its fractions correlated positively with microaggregated material (IA). Some microaggregated sizes showed significant positive correlations with $\mathrm{OC}$ of some deposits. Larger microaggregated sizes correlated with TOC and POC of alluvial wedges and the finest microaggregated size with TOC an MOC in the reservoir downstream. No consistent correlation patterns were found between the percentages of primary particles and the $\mathrm{OC}$ pools and the $\mathrm{C}: \mathrm{N}$ ratio across deposit types. Both total OC and the different pools were positively associated with the sand fraction and negatively with the clay fraction when all the data were considered together, in soils (only significant association with sand) and in the reservoir. By contrast, the clay fraction was associated positively with TOC in wedges and suspended sediment, and with MOC in alluvial wedges. Overall, as may be expected, the OC content was positively correlated with the clay fraction in some de- posits (e.g. alluvial wedges and suspended sediments), indicating selectivity during detachment and transport. However, OC was also positively correlated with the content of sand particles in the soils and reservoir, probably indicating the entrance of organic material from other processes (e.g. in situ formation of C in lakes; Tranvik et al., 2009) in the reservoir and OC formation in the upper layers of sediment. Positive correlations of the sand and OC in soils are probably due to the presence of several samples of sandy soils covered by dense forest ( $25 \%$ of dense forest soil samples had $45-70 \%$ sand).

\section{Discussion}

Hoffman et al. (2013) pointed out that accounting for the non-steady state of $\mathrm{C}$ dynamics along flow paths from hillslopes through river channels and into oceans is crucial to understand the overall $\mathrm{C}$ budget. The redistribution of OC through soil erosion and sediment transport is determined by processes that affect the mineral components of sedi- 

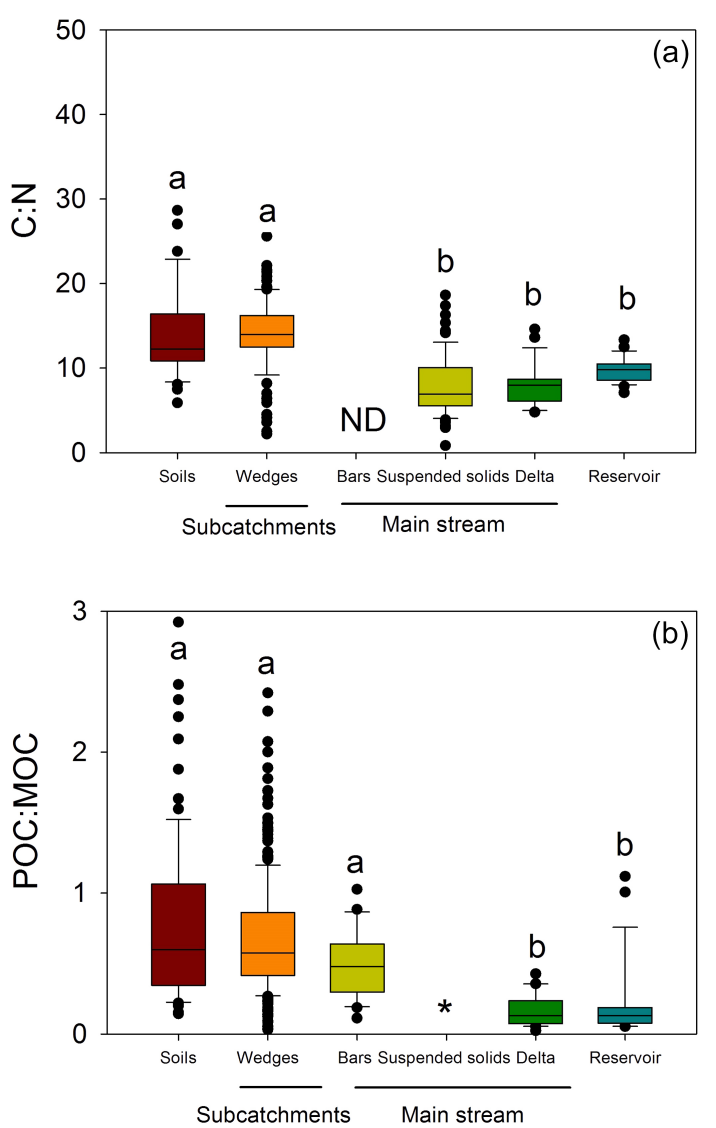

Figure 5. Median, percentiles (10th, 25th, 75th and 90th) and error of $\mathrm{C}: \mathrm{N}$ ratios (A) and POC : MOC (B) ratios in soils and sediments within the Turrilla catchment. Different letters $(\mathrm{a}-\mathrm{b})$ indicate significant differences according to the Kruskal-Wallis test $(p<0.05)$. ND - no data available, ${ }^{*}$ - the suspended solids measured contained only the MOC fraction.

ment (e.g. selectivity and non-selectivity of material during the detachment, transport and deposition phases) and by processes directly affecting the $\mathrm{OC}$ fraction within the sediments (mineralisation, fixation, protection, new OC formation). To better understand the role of soil erosion and sediment transport in the overall $\mathrm{C}$ budget, based on the data reported in this study, the following paragraphs discuss the importance of spatial scale and particle size selectivity as well as the C dynamics of eroded sediments during detachment, transport and deposition phases.

\subsection{OC redistribution: effect of the scale of observation}

All sediments studied within the Turrilla catchment showed, on average, OC concentrations $\left(9.42 \pm 9.01 \mathrm{~g} \mathrm{~kg}^{-1}\right)$ lower than half of those of soils $\left(20.45 \pm 7.71 \mathrm{~g} \mathrm{~kg}^{-1}\right)$, indicating depletion of OC in sediment at this scale. This clearly contrasts with experimental data from erosion plots that usually show higher concentrations of OC in sediments than in the original source soils (Owens et al., 2002; Girmay et al., 2009;
Martínez-Mena et al., 2008). These relatively low OC concentrations found in sediments at the catchment scale raise the question: do the erosion and sediment transport processes lead to $\mathrm{C}$ losses to the atmosphere, or is there another explanation for this difference in $\mathrm{C}$ concentration between soils and sediments?

Previous studies have also found a depletion of OC in sediments measured at a catchment scale (Avnimelech and McHenry, 1984; Haregeweyn et al., 2008; Chaplot and Poesen, 2012). For a small catchment (22 ha), Fiener et al. (2005) observed that sediment deposited in ponds was depleted in OC and clay relative to the source soils, while the sediment collected at the outlet of the pond was enriched in OC and clay compared to soils. This demonstrates the important changes in OC content that may occur during different transport and deposition phases due to preferential deposition. Similar results were reported by Wang et al. (2010) and Rhoton et al. (2006), who found OC impoverishment in deposited sediments within their study catchments, while the sediment transported in suspension and exported out of the catchment was enriched in OC (1.2-3 times) compared to the OC concentration in the source soils. Ran et al. (2014) attributes also lower values of OC than soils for different sedimentary settings, based on several methods, to estimate the OC carbon budget of the Yellow River. In our case, the suspended sediments as well as the reservoir sediments showed significantly higher contents of MOC compared to the other sediment deposits, while the MOC contents in soils was similar to that in reservoir sediments and slightly higher than in suspended sediments. This was also found by Amegashie et al. (2011) and can be probably attributed partially to new, in situ formation of OC in the reservoir (Einsele et al., 2001). We suggest that at these larger scales the decrease of OC in sediments compared to soils is due to a combination of factors related to the spatial scale of observation, namely (i) variety of sediment sources, that dilute the source effect; (ii) interaction of multiple erosion processes, both selective and unselective; (iii) long transport distances that favour continuous remobilisation of sediment facilitating aggregate breakdown and a reduced physical protection of OC; and (iv) the ample time lapse (from hours to several years) that occurred between sediment detachment and its sampling. This contrasts with sediments collected at the plot and hillslope scales, which are collected close to their sources during the detachment and transport phases and often shortly after the erosion event, with little opportunity for OC mineralisation.

\subsection{Mechanisms of OC loss or gain in sediments}

Among all the above-mentioned factors and processes that led to a general decrease of OC in sediments in our studied catchment compared to soils, three of them closely interact: (i) sources of sediment linked to specific erosion processes, (ii) size selectivity, and (iii) processes affecting the organic components of sediments during the erosion and flu- 
Table 2. Percentages of microaggregated particles in different size classes and microaggregation indices (IA, Wang et al., 2010; ASC, Igwe, 2000).

\begin{tabular}{cccccc}
\hline $\begin{array}{c}\text { Group } \\
\text { name }\end{array}$ & $250-63 \mu \mathrm{m}$ & $63-20 \mu \mathrm{m}$ & $20-2 \mu \mathrm{m}$ & IA & ASC \\
\hline $\begin{array}{c}\text { Soils } \\
(N=16)\end{array}$ & $24.99 \pm 16.27 \mathrm{aA}^{*}$ & $3.91 \pm 6.99 \mathrm{aB}$ & $7.34 \pm 16.06 \mathrm{aB}$ & $73.91 \pm 21.03 \mathrm{a}$ & $12.51 \pm 34.91 \mathrm{a}$ \\
\hline $\begin{array}{c}\text { Wedges } \\
(N=25)\end{array}$ & $36.49 \pm 17.88 \mathrm{aA}$ & $9.59 \pm 8.87 \mathrm{bB}$ & 0 & $92.18 \pm 23.50 \mathrm{a}$ & $36.48 \pm 17.92 \mathrm{a}$ \\
\hline $\begin{array}{c}\text { Suspended } \\
\text { sediment } \\
(N=41)\end{array}$ & $3.60 \pm 9.21 \mathrm{bA}$ & $3.19 \pm 3.22 \mathrm{aA}$ & $2.52 \pm 6.40 \mathrm{aA}$ & $18.22 \pm 12.29 \mathrm{~b}$ & $0.98 \pm 2.26 \mathrm{~b}$ \\
\hline $\begin{array}{l}\text { Reservoir } \\
(N=12)\end{array}$ & $6.65 \pm 7.87 \mathrm{bA}$ & $1.46 \pm 2.70 \mathrm{aA}$ & $2.44 \pm 3.46 \mathrm{aA}$ & $24.94 \pm 14.30 \mathrm{~b}$ & $-0.41 \pm 9.71 \mathrm{~b}$ \\
\hline
\end{tabular}

* Different lower case letters mean significant differences among sediments and soil groups. Different capital letters mean significant differences within sediments and soil groups, with regard to microaggregated class sizes (Kruskal-Wallis test, $p<0.05$ ).

vial transport pathway such as burial, mineralisation or new OC formation.

\subsubsection{Size selectivity and sources of sediment}

Wang et al. (2010) explained how selectivity of soil material determines the $\mathrm{OC}$ concentration during transport. They concluded that there was very little mineralisation of TOC during the erosion process, since they found higher $\mathrm{C}: \mathrm{N}$ ratios in sediments than in source soils and similar enrichment ratios of clay and $\mathrm{C}$ in deposited sediments. Based on multiple indicators our data show evidence for the contrary in the middle and lower catchment deposits (suspended sediments, delta and reservoir): higher clay contents, lower $\mathrm{OC}$ and lower $\mathrm{C}: \mathrm{N}$ ratios in sediments than in soils. These findings could indicate $\mathrm{C}$ losses by mineralisation during transport over longer distances. However, the interpretation of narrowed $\mathrm{C}: \mathrm{N}$ ratios as indicators of mineralisation must be done cautiously and in combination with other indicators (Wang et al., 2010), given the complexity of $\mathrm{N}$ behaviour along the fluvial path (Robertson and Groffman, 2007). This is even more complex in sediments of intermittent rivers (as in our case) because nitrification and denitrification processes are also dependent on the drying and rewetting cycles of sediments (Gómez et al., 2012; Arce et al., 2013). In our study, total OC and $\mathrm{N}$ were lower in all sediment deposits compared to soils, with the exception of suspended load. Increase of $\mathrm{N}$ in sediments rich in clay (as suspended load) has been attributed to the presence of ammonium or to the contribution of freshwater algae (Sanchez-Vidal et al., 2013).

The low OC concentration of sediments deposited in the upper catchment may have a different explanation. The sediments in the alluvial wedges showed textural classes and $\mathrm{C}: \mathrm{N}$ ratios similar to those of the soils, but lower OC concentrations. The low OC concentration may be explained by the fact that the sediments originate from deeper soil lay- ers, mobilised by non-selective erosion processes such as bank, gully and channel erosion, with lower OC concentrations than the surface soil. Geomorphological field assessments in the area indicated that these deeper operating erosion processes are indeed important sources of sediments in the catchment (Boix-Fayos et al., 2007). Yet, sediments derived from deep soil layers not only have lower OC concentration but also different OC pool composition (Nadeu et al., 2011) and different turnover rates (Nadeu et al., 2012) than those derived from topsoil. Differences in OC pools between sediment deposits can also be the result of transport conditions due to higher or lower rainfall intensity (MartínezMena et al., 2012; Zhang et al., 2013) or to the discharge. Smith et al. (2013) related high discharge rates with transport of modern $\mathrm{C}$, associated with erosion and the release of organic matter (Sanchez-Vidal et al., 2013), and C from vascular sources (Goñi et al., 2013). Low flows were associated with export of fossil OC (Smith et al., 2013) from biogenic sources dominated by non-vascular plants (Goñi et al., 2013) or from freshwater primary producers (Sanchez-Vidal et al., 2013).

A comparison of the particle sizes of the studied sediments and soils of the catchment points to a selection of transported material in a downstream direction. Finer microaggregated and single particles were present in the suspended load and in the reservoir. In the soils and in the alluvial wedges behind check dams, the material was much more heterogeneous, having similar particle size distribution and larger microaggregates, indicating again its transport by non-selective erosion processes and over short distances.

\subsubsection{Processes affecting organic carbon dynamics during transport and deposition}

The OC concentration, the variation in $\mathrm{C}: \mathrm{N}$ ratios and the different associations of $\mathrm{OC}$ with textural classes in the 
Table 3. Spearman correlation coefficients between primary and microaggregated particle indicators and organic carbon pools and $\mathrm{C}: \mathrm{N}$ ratios.

\begin{tabular}{|c|c|c|c|c|c|c|c|c|}
\hline \multirow[b]{2}{*}{ Groups } & \multicolumn{4}{|c|}{ Microaggregated particles } & \multicolumn{4}{|c|}{ Primary particles } \\
\hline & $250-63 \mu \mathrm{m}$ & $63-20 \mu \mathrm{m}$ & $20-2 \mu \mathrm{m}$ & IA & ASC & Sand & Silt & Clay \\
\hline \multicolumn{9}{|c|}{ TOC } \\
\hline All data & & $0.36^{\mathrm{a}}$ & - & 0.32 & - & 0.70 & -0.26 & -0.64 \\
\hline Soils & - & - & - & - & -0.51 & 0.57 & - & - \\
\hline Wedges & - & 0.36 & & - & - & -0.49 & - & 0.49 \\
\hline Suspended sed & - & & - & $0.34^{\mathrm{b}}$ & - & - & -0.48 & 0.47 \\
\hline Reservoir & - & - & 0.66 & & - & 0.63 & - & -0.71 \\
\hline \multicolumn{9}{|c|}{ POC } \\
\hline All data & 0.58 & - & 0.51 & 0.58 & - & - & - & -0.27 \\
\hline Soils & - & - & - & - & -0.61 & - & - & - \\
\hline Wedges & 0.52 & - & - & 0.650 & 0.517 & -0.72 & 0.45 & - \\
\hline Suspended sed & - & - & - & - & - & - & - & - \\
\hline Reservoir & & - & - & - & -0.67 & 0.82 & - & -0.87 \\
\hline \multicolumn{9}{|c|}{ MOC } \\
\hline All data & - & 0.46 & - & - & - & - & - & - \\
\hline Soils & - & - & - & - & - & 0.58 & - & - \\
\hline Wedges & - & 0.57 & & - & - & - & - & 0.72 \\
\hline Suspended sed & - & - & - & - & - & - & - & - \\
\hline Reservoir & - & - & 0.66 & & - & 0.62 & - & -0.72 \\
\hline \multicolumn{9}{|c|}{$\mathrm{C}: \mathrm{N}$} \\
\hline All data & & 0.49 & 0.333 & 0.27 & -0.55 & 0.41 & -0.26 & -0.22 \\
\hline Soils & & 0.51 & & & -0.70 & - & - & - \\
\hline Wedges & -0.55 & 0.75 & & - & -0.55 & - & - & - \\
\hline Suspended sed & -0.40 & - & 0.45 & & - & - & -0.25 & - \\
\hline Reservoir & - & - & - & - & - & - & - & - \\
\hline
\end{tabular}

${ }^{\mathrm{a}}$ Only significant correlations are shown. Bold correlation indices are for $p<0.005$, the rest have $p<0.05$. ${ }^{\mathrm{b}}$ This correlation has $p<0.06$

studied deposits indicate different processes of loss or gain of OC during the transport along the studied catchment.

The $\mathrm{C}: \mathrm{N}$ ratios showed clearly two groups (Fig. 5a): lower values in suspended sediments, delta and reservoir sediments, and higher values in soils and alluvial wedges. This suggests a relatively low mineralisation of OC in the sediments of alluvial wedges due to efficient burial or a short transport time, as reported also by Smith et al. (2013) and suggested by Ran et al. (2014). Further downstream in the suspended sediments, delta and reservoir sediments, the lower $\mathrm{C}: \mathrm{N}$ ratios could indicate mineralisation of $\mathrm{OC}$ in sediment transported over longer distances (Fig. 5a) (Bouchez et al., 2010; Hovius et al., 2011; Raymond and Bauer, 2001). Ran et al. (2014) recently reported a mineralisation of $27 \%$ during erosion and transport of sediment and associated OC through the Yellow River catchment. Although, as previously stated, interpretation of $\mathrm{C}: \mathrm{N}$ ratios for mineralisation must be done with caution. Nevertheless, and interestingly, the observed trend in the $\mathrm{C}: \mathrm{N}$ ratios in soil and among different sediment deposits was consistent with that found in the POC:MOC ratios (Fig. 5a and b) which support our statement that the degree of OC mineralisation is increased during transport along the flow path (prevalence of more recalcitrant fractions downstream).

Apart from the indications of OC mineralisation, the MOC concentration of suspended sediments was low and very variable $(3.8-0.1 \%)$, which can be attributed to the diverse characteristics of the events that mobilise material from different sources (Smith et al., 2013; Goñi et al., 2013; Sanchez-Vidal et al., 2013) or to sediments mobilised by different erosion processes (Nadeu et al., 2011, 2012).

Furthermore, the relatively high OC content of the reservoir sediments could indicate in situ organic matter formation from ecological lake processes stimulating primary production (Einsele et al., 2001) or allochthonous OC input from the establishment of vegetation and soil formation in the frequently exposed upper sediment layers. Moreover, while other deposits (wedges and suspended sediment) showed the well-known relationship between clay and OC (RodriguezRodriguez, 2004; Rhoton et al., 2006; Martínez-Mena et 
al., 2008), reservoir sediments presented a correlation between the sand fraction and concentration of $\mathrm{OC}$ in the two pools that could be indicative of in situ $\mathrm{C}$ formation. Autochthonous input of organic matter in rivers and lakes can account for around $50 \%$ of the total organic matter in aquatic ecosystems of tropical-semiarid and dryland areas (Kunz et al., 2011; Medeiros and Arthington, 2011). The fluctuation in autochthonous organic matter production in riverine ecosystems depends on the input from terrestrial land uses in the drainage area, with thresholds in which terrestrially derived $\mathrm{C}$ is replaced by in-stream algal productivity (Hagen et al., 2010). However, it can also be influenced by river hydrodynamics (Cabezas and Comín, 2010; Devesa-Rey and Barral, 2012). In particular, in Mediterranean river ecosystems there is an important seasonal shift between inputs of allochthonous and autochthonous organic matter, with high primary production in spring and allochthonous organic matter inputs in autumn (Romaní et al., 2013). Given that C:N ratios of allochthonous organic matter (more recalcitrant and resistant to degradation by microorganisms) tend to be higher than in situ-produced organic matter (Devesa-Rey and Barral, 2012), shifts between one and the other will change OC decomposition rates and dynamics.

The combined interpretation of OC pools, textural analysis and $\mathrm{C}: \mathrm{N}$ ratios in the soils and different sediment deposits indicates that catchment-scale $\mathrm{C}$ redistribution by lateral fluxes is controlled by both the organic and the mineral nature of sediments:

1. Sediments in upstream depositional areas (alluvial wedges) showed significantly lower $\mathrm{C}$ concentrations than soils, but sediment texture and $\mathrm{C}$ characteristics were more similar to those in soils than to those in sediments transported further downstream, showing little indication of mineralisation (similar $\mathrm{C}: \mathrm{N}$ than in soils) and low selectivity of particles (similar primary and aggregated particle size distribution to soils). This is probably related to the non-selective character of dominant erosion processes and to the proximity of sediment sources, giving little time for aggregate breakdown or $\mathrm{C}$ mineralisation.

2. In middle stream areas, preferential deposition of coarse particles can be seen in the channel bars, enriched in the sand fraction and showing the lowest concentrations of all $\mathrm{C}$ fractions, among all deposits.

3. Downstream, the suspended sediment in transit and the sedimentary deposits (delta and reservoir) showed higher contents of fine particles (clay and silt), accompanied by lower $\mathrm{C}: \mathrm{N}$ ratios and a slightly higher $\mathrm{C}$ concentration, though still lower than in soils. The sand contents of the delta and reservoir deposits indicate also bedload contribution to the deposits downstream. The differences in the $\mathrm{C}: \mathrm{N}$ ratio combined with other indicators could point to different degrees of mineralisation of $\mathrm{OC}$ along the flow path, the $\mathrm{OC}$ being protected more when associated with large microaggregated particles in soils and in the deposits of the upper catchment areas.

\subsection{Implications for the fate of eroded OC}

The results from this study suggest that sediment reaching depositional settings is composed of a heterogeneous mixture of OC particles in different stages of decomposition. The role of the source area, sediment transport and postdeposition processes were revealed as crucial to understanding the characteristics of the $\mathrm{OC}$ and differences among the analysed deposits and distinct phases of the erosion process. Although OC mineralisation fluxes were not addressed directly, the decrease in the level of particle aggregation downstream suggests a potential increase in OC decomposition by microorganisms, leading to higher potential mineralisation rates. Distance from source areas, selective transport and deposition of sediments were identified as important factors controlling the characteristics of the OC in sediments and its fate.

\section{Conclusions}

A non-homogeneous redistribution of $\mathrm{OC}$ by water flow takes place within catchments, which can be associated with the geomorphological processes and dynamics of sediment transport and deposition. The redistribution of OC in sediments at the catchment scale is controlled by factors affecting their organic component (mineralisation, protection of OC within microaggregates and new OC formation in some deposits) and by factors affecting their mineral component (selectivity of sediment sizes during the detachment, transport and deposition phases of erosion, and the type of erosion processes: selective versus non-selective).

The processes that determine OC concentration at different pools are related also to the different phases of erosion (detachment, transport and deposition): (i) during detachment - size selectivity, type of erosion process and source of material; (ii) during transport - size selectivity, protection of OC in microaggregates and transport distances, and (iii) during deposition and in the post-deposition phase - size selectivity, protection of $\mathrm{OC}$ from mineralisation by stabilisation of microaggregates and burial and new OC formation are important.

The OC mobilised in catchments is associated very closely with the sediment dynamics and can have long residence times linked to the fate of the sediments. In addition, it can be increased by ecological processes and by replacement in eroded areas, converting catchments into relevant sinks for $\mathrm{C}$ budgets. 
Acknowledgements. This work has been financially supported by the project ESUMA (11859/PI/09) of the Seneca Foundation, Regional Government of Murcia (Spain) and by the project SOGLO (P7/24 IAP BELSPO) from the Belgian Government. Joris de Vente was supported by a Juan de la Cierva contract (JCI-2011-08941). Elisabet Nadeu acknowledges financial support from an FPI predoctoral fellowship of the former Ministry of Science and Innovation (BES-2008-002379). We also thank the MIRAGE project (EC, FP7-ENV-2007-1) and Gonzalo G. Barberá for facilitating the installation of the suspended solids sampling devices. Gonzalo G. Barberá advised also about the statistical approach. Rosa Gómez Cerezo, María del Mar Sánchez Montoya and Marisa Arce are thanked for providing a part of the samples of the fluvial bars group. Many thanks to Pedro Pérez Cutillas for producing Fig. 1.

Edited by: M. Gooseff

\section{References}

Amegashie, B. K., Quansah, C., Agyare, W. A., Tamene, L., and Vlek, P. L. G.: Sediment-bound nutrient export from five small reservoir catchments and its implications for the Sudan savanna zone of Ghana, Lakes Reserv. Res. Manage., 16, 61-76, 2011.

Arce, M. I., Gómez, R., Suárez, M. L., and Vidal-Abarca, M. R.: Denitrification rates and controlling factors in two agriculturally influenced temporary Mediterranean saline streams, Hydrobiologia, 700, 169-185, 2013.

Aufdenkampe, A. K., Mayorga, E., Raymond, P. A., Melack, J. M., Doney, S. C., Alin, S. R., Aalto, R. E., and Yoo, K.: Riverine coupling of biogeochemical cycles between land, oceans, and atmosphere, Front. Ecol. Environ., 9, 53-60, 2011.

Avnimelech, Y. and McHenry, J. R.: Enrichment of transported sediments with organic carbon, nutrients and clay, Soil Sci. Soc. Am. J., 48, 259-266, 1984.

Berhe, A. A. and Kleber, M.: Erosion, deposition, and the persistence of soil organic matter: Mechanistic considerations and problems with terminology, Earth Surf. Proc. Land., 38, 908912, 2013

Boix-Fayos, C., Barbera, G. G., Lopez-Bermudez, F., and Castillo, V. M.: Effects of check dams, reforestation and land use changes on river channel morphology: Case study of the Rogativa catchment (Murcia, Spain), Geomorphology, 91, 103-123, 2007.

Boix-Fayos, C., de Vente, J., Martínez-Mena, M., Barberá, G. G., and Castillo, V.: The impact of land use change and check-dams on catchment sediment yield, Hydrol. Process., 22, 4922-4935, 2008.

Boix-Fayos, C., de Vente, J., Albaladejo, J., and Martínez-Mena, M.: Soil carbon erosion and stock as affected by land use changes at the catchment scale in Mediterranean ecosystems, Agr. Ecosyst. Environ., 133, 75-85, 2009.

Bouchez, J., Beyssac, O., Galy, V., Gaillardet, J., France-Lanord, C., Maurice, L., and Moreira-Turcq, P.: Oxidation of petrogenic organic carbon in the Amazon floodplain as a source of atmospheric $\mathrm{CO}_{2}$, Geology, 38, 255-258, 2010.

Cabezas, A. and Comín, F. A.: Carbon and nitrogen accretion in the topsoil of the Middle Ebro River Floodplains (NE Spain):
Implications for their ecological restoration, Ecol. Eng., 36, 640652, 2010.

Cambardella, C. A. and Elliot, E. T.: Particulate soil organic-matter changes across a grassland cultivation sequence, Soil Sci. Soc. Am. J., 56, 777-783, 1992.

Chaplot, V. and Poesen, J.: Sediment, soil organic carbon and runoff delivery at various spatial scales, Catena, 88, 46-56, 2012.

Devesa-Rey, R. and Barral, M. T.: Allochthonous versus autochthonous naturally occurring organic matter in the Anllóns river bed sediments (Spain), Environ. Earth Sci., 66, 773-782, 2012.

Einsele, G., Yan, J., and Hinderer, M.: Atmospheric carbon burial in modern lake basins and its significance for the global carbon budget, Global Planet. Change, 30, 167-195, 2001.

Evans, W., Hales, B., and Strutton, P. G.: $P \mathrm{PO}_{2}$ distributions and air-water $\mathrm{CO}_{2}$ fluxes in the Columbia River estuary, Estuar. Coast. Shelf Sci., 117, 260-272, 2013.

Fiener, P., Auerswald, K., and Weigand, S.: Managing erosion and water quality in agricultural watersheds by small detention ponds, Agr. Ecosyst. Environ., 110, 132-142, 2005.

Girmay, G., Singh, B. R., Nyssen, J., and Borrosen, T.: Runoff and sediment-associated nutrient losses under different land uses in Tigray, Northern Ethiopia, J. Hydrol., 376, 70-80, 2009.

Gómez, R., Arce, I. M., Sánchez, J. J., and Sánchez-Montoya, M. M.: The effects of drying on sediment nitrogen content in a Mediterranean intermittent stream: A microcosms study, Hydrobiologia, 679, 43-59, 2012.

Goñi, M. A., Hatten, J. A., Wheatcroft, R. A., and Borgeld, J. C.: Particulate organic matter export by two contrasting small mountainous rivers from the Pacific Northwest, U.S.A., J. Geophys Res.-Biogeo., 118, 112-134, 2013.

Hagen, E. M., McTammany, M. E., Webster, J. R., and Benfield, E. F.: Shifts in allochthonous input and autochthonous production in streams along an agricultural land-use gradient, Hydrobiologia, 655, 61-77, 2010.

Harden, J. W., Sharpe, J. M., Parton, W. J., Ojima, D. S., Fries, T. L., Huntington, T. G., and Dabney, S. M.: Dynamic replacement and loss of soil carbon on eroding cropland, Global Biogeochem. Cy., 13, 885-901, 1999.

Haregeweyn, N., Poesen, J., Deckers, J., Nyssen, J., Haile, M., Govers, G., Verstraeten, G., and Moeyersons, J.: Sediment-bound nutrient export from micro-dam catchments in Northern Ethiopia, Land Degrad. Develop., 19, 136-152, 2008.

Hoffmann, T., Mudd, S. M., van Oost, K., Verstraeten, G., Erkens, G., Lang, A., Middelkoop, H., Boyle, J., Kaplan, J. O., Willenbring, J., and Aalto, R.: Short Communication: Humans and the missing C-sink: erosion and burial of soil carbon through time, Earth Surf. Dynam. Discuss., 1, 93-112, 2013.

Hovius, N., Galy, A., Hilton, R. G., Sparkes, R., Smith, J., Shuh-Ji, K., Hongey, C., In-Tian, L., and Joshua West, A.: Erosion-driven drawdown of atmospheric carbon dioxide: The organic pathway, Appl.Geochem., 26, S285-S287, 2011.

IGME: Mapa Geológico de España 1 : 50 000, Nerpio, 909, Instituto Geológico y Minero de España, 1978.

Igwe, C. A.: Nutrient losses in runoff and eroded sediments from soils of central eastern Nigeria, Polish J. Soil Sci., 33, 67-75, 2000.

IUSS Working Group WRB: World reference base for soil resources, Word Soil Resources Report 103, FAO, Rome, 2006. 
Kunz, M. J., Anselmetti, F. S., West, A., Wehrli, B., Vollenweider, A., Thüring, S., and Senn, D. B.: Sediment accumulation and carbon, nitrogen, and phosphorus deposition in the large tropical reservoir Lake Kariba (Zambia/Zimbabwe), J. Geophys. Res.Biogeo., 116, G03003, doi:10.1029/2010JG001538, 2011.

Le Quéré, C., Raupach, M. R., Canadell, J. G., Marland, G., Bopp, L., Ciais, P., Conway, T. J., Doney, S. C., Feely, R. A., Foster, P., Friedlingstein, P., Gurney, K., Houghton, R. A., House, J. I., Huntingford, C., Levy, P. E., Lomas, M. R., Majkut, J., Metzl, N., Ometto, J. P., Peters, G. P., Prentice, I. C., Randerson, J. T., Running, S. W., Sarmiento, J. L., Schuster, U., Sitch, S., Takahashi, T., Viovy, N., Van Der Werf, G. R., and Woodward, F. I.:. Trends in the sources and sinks of carbon dioxide, Nat. Geosci., 2, 831-836, 2009.

Martínez-Mena, M., Lopez, J., Almagro, M., Boix-Fayos, C., and Albaladejo, J.: Effect of water erosion and cultivation on the soil carbon stock in a semiarid area of South-East Spain, Soil Till. Res., 99, 119-129, 2008.

Martínez-Mena, M., López, J., Almagro, M., Albaladejo, J., Castillo, V., Ortiz, R., and Boix-Fayos, C.: Organic carbon enrichment in sediments: Effects of rainfall characteristics under different land uses in a Mediterranean area, Catena, 94, 36-42, 2012.

Meade, R. H. and Stevens Jr., H. H.: Strategies and equipment for sampling suspended sediment and associated toxic chemicals in large rivers - with emphasis on the Mississippi River, Sci. Total Environ., 97-98, 125-135, 1990.

Medeiros, E. S. F. and Arthington, A. H.: Allochthonous and autochthonous carbon sources for fish in floodplain lagoons of an Australian dryland river, Environ. Biol. Fish., 90, 1-17, 2011.

Nadeu, E., de Vente, J., Martinez-Mena, M., and Boix-Fayos, C.: Exploring particle size distribution and organic carbon pools mobilized by different erosion processes at the catchment scale, J. Soils Sediments, 11, 667-678, 2011.

Nadeu, E., Berhe, A. A., de Vente, J., and Boix-Fayos, C.: Erosion, deposition and replacement of soil organic carbon in Mediterranean catchments: a geomorphological, isotopic and land use change approach, Biogeosciences, 9, 1099-1111, doi:10.5194/bg-9-1099-2012, 2012.

Nadeu, E., Van Oost, K., Boix-Fayos, C., and de Vente, J.: Importance of land use patterns for erosion-induced carbon fluxes in a Mediterranean catchment, Agr. Ecosyst. Environ., 189, 181-189, 2014.

Nadeu, E., Quiñonero-Rubio, J. M., de Vente, J., and Boix-Fayos, C.: The influence of catchment morphology, lithology and land use on soil organic carbon export in a Mediterranean mountain region, Catena, 126, 117-125, doi:10.1016/j.catena.2014.11.006, 2015.

Owens, L. B., Malone, R. W., Hothem, D. L., Starr, G. C. and Lal, R.: Sediment carbon concentration and transport from small watersheds under various conservation tillage practices, Soil Till. Res., 67, 65-73, 2002.

Quiñonero-Rubio, J. M., Boix-Fayos, C., and de Vente, J.: Development and application of a multi-factorial sediment connectivity index at the catchment scale, Desarrollo y aplicación de un índice multifactorial de conectividad de sedimentos a escala de cuenca, 39, 203-223, 2013.

Quiñonero-Rubio, J. M., Nadeu, E., Boix-Fayos, C., and de Vente, J.: Evaluation of the effectiveness of forest restoration and check- dams to reduce catchment sediment yield, Land Degrad. Develop., doi:10.1002/ldr.2331, in press, 2014.

Ran, L., Lu, X. X., and Xin, Z.: Erosion-induced massive organic carbon burial and carbon emission in the Yellow River basin, China, Biogeosciences, 11, 945-959, doi:10.5194/bg-11945-2014, 2014.

Raymond, P. A. and Bauer, J. E.: Riverine export of aged terrestrial organic matter to the North Atlantic Ocean, Nature, 409, 497500, 2001.

Rhoton, F. E., Emmerich, W. E., Goodrich, D. C., Miller, S. N., and McChesney, D. S.: Soil geomorphological characteristics of a semiarid watershed: Influence on carbon distribution and transport, Soil Sci. Soc. Am. J., 70, 1532-1540, 2006.

Robertson, G. P. and Groffman, P. M.: Nitrogen transformations, in: Soil Microbiology, Biogeochemistry, and Ecology, edited by: Paul, E. A., Springer, New York, NY, USA, 341-364, 2007.

Rodriguez-Rodriguez, A., Guerra, A., Arbelo, C., Mora, J. L., Gorrín, S. P., and Armas, C.: Forms of eroded soil organic carbon in andosols of the Canary Islands (Spain), Geoderma, 121, 205219, 2004.

Romaní, A. M., Amalfitano, S., Artigas, J., Fazi, S., Sabater, S., Timoner, X., Ylla, I., and Zoppini, A.: Microbial biofilm structure and organic matter use in mediterranean streams, Hydrobiologia, 719, 43-58, 2013.

Sanchez-Vidal, A., Higueras, M., Martí, E., Liquete, C., Calafat, A., Kerhervé, P., and Canals, M.: Riverine transport of terrestrial organic matter to the North Catalan margin, NW Mediterranean Sea, Prog. Oceanogr., 118, 71-80, 2013.

Smith, J. C., Galy, A., Hovius, N., Tye, A. M., Turowski, J. M., and Schleppi, P.: Runoff-driven export of particulate organic carbon from soil in temperate forested uplands, Earth Planet. Sc. Lett., 365, 198-208, 2013.

Stallard, R. F.: Terrestrial sedimentation and the carbon cycle: coupling weathering and erosion to carbon burial, Global Biogeochem. Cy., 12, 231-257, 1998.

Tranvik, L. J., Downing, J. A., Cotner, J. B., Loiselle, S. A., Striegl, R. G., Ballatore, T. J., Dillon, P., Finlay, K., Fortino, K., Knoll, L. B., Kortelainen, P. L., Kutser, T., Larsen, S., Laurion, I., Leech, D. M., Leigh McCallister, S., McKnight, D. M., Melack, J. M., Overholt, E., Porter, J. A., Prairie, Y., Renwick, W. H., Roland, F., Sherman, B. S., Schindler, D. W., Sobek, S., Tremblay, A., Vanni, M. J., Verschoor, A. M., Von Wachenfeldt, E., and Weyhenmeyer, G. A.: Lakes and reservoirs as regulators of carbon cycling and climate, Limnol. Oceanogr., 54, 2298-2314, 2009.

Trimble, S. W.: A sediment budget for Coon Creek basin in the Driftless Area, Wisconsin, 1853-1977, Am. J. Sci., 283, 454474, 1983.

Van Hemelryck, H., Govers, G., Van Oost, K.. and Merckx, R.: Evaluating the impact of soil redistribution on the in situ mineralization of soil organic carbon, Earth Surf. Proc. Land., 36, 427-438, 2011.

Van Oost, K., Quine, T. A., Govers, G., De Gryze, S., Six, J., Harden, J. W., Ritchie, J. C., McCarty, G. W., Heckrath, G., Kosmas, C., Giraldez, J. V., da Silva, J. R. M., and Merckx, R.: The impact of agricultural soil erosion on the global carbon cycle, Science, 318, 626-629, 2007.

Van Oost, K., Verstraeten, G., Doetterl, S., Notebaert, B., Wiaux, F., Broothaerts, N., and Six, J.: Legacy of human-induced C erosion 
and burial on soil-atmosphere C exchange, P. Natl. Acad. Sci. USA, 109, 19492-19497, 2012.

Verstraeten, G., Bazzoffi, P., Lajczak, A., Rãdoane, M., Rey, F., Poesen, J., and De Vente, J.: Reservoir and Pond Sedimentation in Europe, John Wiley \& Sons, Chichester, UK, 757-774, 2006.

Walling, D. E. and Fang, D.: Recent trends in the suspended sediment loads o the world's rivers, Global Planet. Change, 39, 111126, 2003.

Wang, Z., Govers, G., Steegen, A., Clymans, W., Van den Putte, A., Langhans, C., Merckx, R., and Van Oost, K.: Catchment-scale carbon redistribution and delivery by water erosion in an intensively cultivated area, Geomorphology, 124, 65-74, 2010.
Wisser, D., Frolking, S., Hagen, S., and Bierkens, M. F. P.: Beyond peak reservoir storage? A global estimate of declining water storage capacity in large reservoirs, Water Resour. Res., 49, 5732 5739, 2013.

Zhang, X., Li, Z., Tang, Z., Zeng, G., Huang, J., Guo, W., Chen, X., and Hirsh, A.: Effects of water erosion on the redistribution of soil organic carbon in the hilly red soil region of southern China, Geomorphology, 197, 137-144, 2013. 